MRN

30,7

460

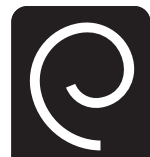

Emerald

Management Research News

Vol. 30 No. 7,2007

pp. $460-475$

(C) Emerald Group Publishing Limited $0140-9174$

DOI $10.1108 / 01409170710759694$

\section{Intangible project management assets as determinants of competitive advantage}

\author{
Gita Mathur \\ Department of Organization and Management, College of Business, San José \\ State University, San José, California, USA \\ Kam Jugdev \\ Project Management and Strategy, Centre for Innovative Management, \\ Athabasca University, Alberta, Canada \\ Schulich School of Engineering, University of Calgary, Alberta, Canada, and \\ Tak Shing Fung \\ Faculty of Nursing, University of Calgary, Alberta, Canada
}

\begin{abstract}
Purpose - To explore the role of intangible project management assets in achievement of competitive advantage from the project management process through it being valuable, rare, inimitable, and having organizational support.

Design/methodology/approach - Data were collected on tangible and intangible project management process assets and competitive characteristics of the project management process using an online survey of North American Project Management Institute ${ }^{\circledR}$ members. Three key tangible asset factors, one intangible asset factor, and three competitive characteristics were identified using exploratory factor analysis. The relationship between these project management assets and project management process characteristics are examined using multivariate analysis.

Findings - Intangible project management assets are found to be a source of competitive advantage, directly and through a mediating role in the relationship between tangible project management assets and the competitive characteristics of the project management process.

Practical implications - This study highlights the importance of developing intangible project management assets, in addition to investment in tangible project management assets, to achieve competitive advantage from the process.

Research limitations/implications - This was an exploratory study. The authors expect to further develop the instrument, refine the model and constructs, and test it with a larger sample.

Originality/value - Few papers have used the Resource Based View lens and applied it to project management. This paper contributes to the literature on the Resource Based View of the firm and to an improved understanding of project management as a source of competitive advantage.
\end{abstract}

Keywords Competitive advantage, Project management, Corporate strategy, Intangible assets

Paper type Research paper

\section{Introduction}

The Resource Based View of the firm examines competitive advantage in terms of a company's resources or assets. A company has many resources (e.g. financial, human, organizational, physical, social and technological). These resources can be tangible (concrete; physical; codified or based on explicit knowledge) or intangible (tacit;

This study was supported by San José State University, Athabasca University, and a grant from the Social Sciences and Research Council of Canada. The authors would like to acknowledge the study participants for completing the survey. The authors thank the reviewers for their helpful feedback. 
unspoken but understood). Only a subset of a company's resources, classified as strategic assets, contributes to its competitive advantage (Amit and Schoemaker, 1993). The VRIO framework has emerged from this perspective as a useful way of characterizing strategic assets as those assets that are Valuable (provide economic value), Rare (unique), Inimitable (difficult to copy), and involve Organizational Support (management support, processes, and systems) (Barney, 1991, 2002). In this framework, competitive advantage is conceptualized to have several levels. A company achieves competitive parity when it has resources that are valuable. When it has resources that are both valuable and rare, it achieves a temporary competitive advantage. When it has resources that are valuable, rare, and inimitable, it achieves a sustained competitive advantage. As a company transitions from competitive parity to a sustained competitive advantage, there is increasing evidence of organizational support in relation to these resources.

While companies are increasingly focusing on the project management process to improve business results, little research has been done to fully understand how project management contributes to competitive advantage (DeFillippi and Arthur, 1998). It is therefore crucial that the discipline develop analytical instruments to enable us to understand how different project management elements contribute to competitive advantage.

An earlier paper draws on the VRIO framework and data gathered from an online survey of a random sample of North American Project Management Institute ${ }^{\circledR}$ members to identify tangible and intangible project management assets and competitive characteristics of the project management process through exploratory factor analysis (Jugdev and Mathur, 2006). Three key tangible asset factors, one intangible asset factor, and three competitive characteristics were identified. This paper extends that work and presents the results of an analysis of the relationship between the project management asset factors (independent variables) and the factors representing the VRIO characteristics of the project management process (dependent variable). It examines the direct relationship between the tangible and intangible factors and the VRIO characteristics and the mediating role of the intangible factor in the relationship between the tangible factors and the dependent variable.

The sections that follow include the literature review, presentation of the study methodology, discussion of findings, conclusions, limitations, and the next steps in the ongoing research program.

\section{Literature review}

The Resource Based View and the perspective that strategic assets contribute to a firm's competitive advantage are widely accepted in the literature. Strategic assets (e.g. intellectual property rights, reputation, brand, and culture) are resources that involve explicit and tacit knowledge (Eisenhardt and Santos, 2000; Kaplan et al., 2001; Kogut, 2000; Nonaka, 1994) that is embedded in a company's unique skills, knowledge, resources, and ways of working (Foss, 1997; Rumelt et al., 1994). The Resource Based View and Barney's VRIO framework have been widely used in empirical studies on strategic assets (Barney, 1998; Castanias and Helfat, 2001; Lopez, 2001; Montealegre, 2002; Ray et al., 2004; Wiggins and Ruefli, 2002; Zahra and Nielsen, 2002). In 2005, the Academy of Management indicated that over 200 academic papers were published using the Resource Based View (AoM, 2005).

While much has been published using the Resource Based View and VRIO framework, there are, however, few studies that use the Resource Based View or the 
MRN

30,7

462
VRIO framework to discuss how project management might contribute to a company's competitive advantage (DeFillippi and Arthur, 1998).

As a discipline, project management stems from engineering, decision sciences, and operations management and currently draws from management theory for its theoretical foundation (Koskela and Howell, 2002; Packendorff, 1995). Project management is a set of practices applied to a project to deliver a result, product, or service (PMI, 2004) based on tangible and intangible assets (DeFillippi and Arthur, 1998; Fernie et al., 2003). Tangible assets are based on codified or explicit knowledge while intangible assets are based on tacit knowledge. Codified and tacit knowledge have also been labeled as "know-what" and "know-how" (Nonaka, 1994). To date, most of the project management literature has focused on the tangible assets and codified knowledge shared through project management offices, methodologies, databases, documents, and tools and techniques (Kloppenborg and Opfer, 2002; Ulri and Ulri, 2000). Some of the literature promote project management maturity models which consist of progressive stages of codified processes and practices (ESI-International, 2001; Hartman, 2000; Ibbs and Kwak, 2000; MicroFrame, 2001). These tangible assets are valuable, but they are not rare or inimitable, and therefore do not meet the VRIO criteria for sources of competitive advantage. Project maturity models are not found to significantly improve a company's return on investment (Jugdev and Thomas, 2002).

While discussion on resources and assets within the project management literature has primarily been focused on tangible assets, intangible project management assets are more likely to be rare and inimitable, and therefore more likely to be sources of competitive advantage. Intangible project management assets need further study. Intangible project management assets include tacit knowledge, application and sharing of tacit knowledge, and processes and relationships for facilitating this sharing. While explicit knowledge is more formal, codified, and transmitted systematically (Polanyi, 1966), tacit knowledge is shared informally through social exchanges (Granovetter, 1985; Tsoukas, 1991). Examples of how this sharing occurs in the project management context include brainstorming, mentoring, learning through shadowing, and storytelling. Project teams often share knowledge through informal exchange of ideas and practice in communities of practice (groups where members regularly engage in sharing and learning, based on their common interests) (Lesser, 2000). Knowledge is viewed as inimitable when socially complex and causally ambiguous (Barney, 1999; Mata et al., 1995). Tacit project management knowledge can be viewed as difficult to imitate and therefore a source of competitive advantage. However, there are few empirical studies on tacit knowledge management in the project management context.

This paper makes a contribution to the growing body of empirical works on strategic assets and to the literature on project management. It contributes to the understanding of project management as a source of competitive advantage and highlights the importance of intangible project management assets.

\section{Conceptual model}

Project management's potential as a source of competitive advantage will depend on the extent to which a company develops the project management process to have VRIO characteristics. An investment in tangible project management assets primarily enhances the Valuable and Organizational Support dimensions (Barney, 2002). As such assets are not rare (e.g. unless the organization owns the copyright or trademark), competing firms can copy them so these investments do not improve a firm's 
competitive position. However, intangible assets can be Valuable, Rare, and Inimitable, with Organizational Support (Barney, 2002). Companies often do not recognize the value of intangible assets.

We use a high-level conceptual model (Figure 1) to link the achievement of VRIO characteristics of the project management process (dependent variable) to tangible and intangible assets (independent variables). Conceptually, this model shows latent (unobservable) variables. These latent variables are split into tangible and intangible assets drawing on the literature that discusses the Resource Based View of the firm (Barney and Zajac, 1994; Castanias and Helfat, 1991; Chakraborty, 1997; Hawawini et al., 2002; Kogut and Zander, 1993; Teece et al., 1997).

In examining the direct role of tangible and intangible project management elements as determinants of competitive advantage, we hypothesize based on the literature, that tangible project management assets will result in the project management process being valuable and having organizational support, while intangible project management assets will result in the project management process being valuable, having organizational support and, in addition, being rare and inimitable. These hypotheses are stated as $H 1$ through $H 6$ below and portrayed as paths in Figures 1 and 2.

H1. Tangible project management assets will result in the project management process being Valuable $(V)$.

H2. Tangible project management assets will result in the project management process having Organizational Support $(O)$.

H3. Intangible project management assets will result in the project management process being Valuable $(V)$.

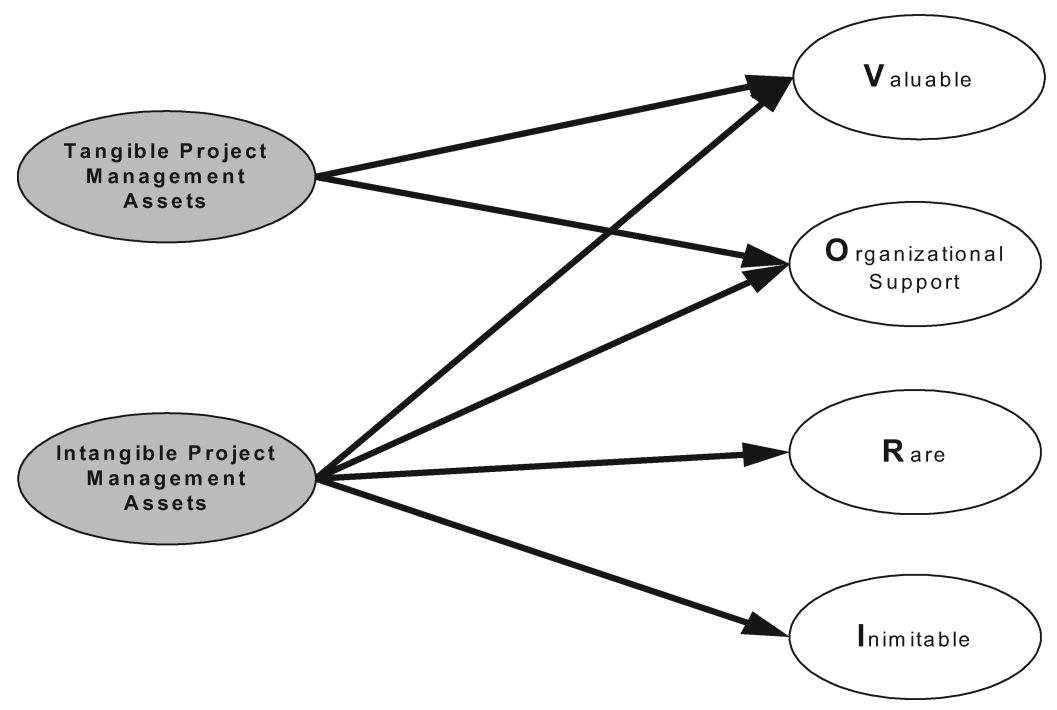

Figure 1.

Conceptual model linking tangible and intangible assets and VRIO characteristics of the project management process 
MRN

30,7

464

H4. Intangible project management assets will result in the project management process having Organizational Support $(O)$.

H5. Intangible project management assets will result in the project management process being Rare $(R)$.

H6. Intangible project management assets will result in the project management process being Inimitable $(I)$.

While tangible project management assets may not directly result in the process being rare or inimitable, we expect that an investment in tangible project management assets will enhance intangible project management assets. For example, it can be expected that project management maturity and the capability to share codified knowledge will facilitate the sharing of know-how; sharing explicit knowledge will lead to sharing tacit knowledge (Nonaka et al., 2000); and tangible and intangible assets are often bundled to execute business processes (Ray et al., 2004; Sabherwal and Becerra-Fernandez, 2003). We conceptualize a mediating role for intangible project management assets in the relationship between tangible project management assets and the VRIO characteristics of the project management process (Figure 2).

We hypothesize that tangible project management assets will result in the project management process being rare and inimitable when mediated by intangible project management assets, even though the tangible assets will not directly result in the

Project Management Assets— Achievement of VRIO characteristics of

Figure 2.

Mediating role of intangible assets in the relationship between tangible assets and VRIO characteristics of the project management process Project Management Process
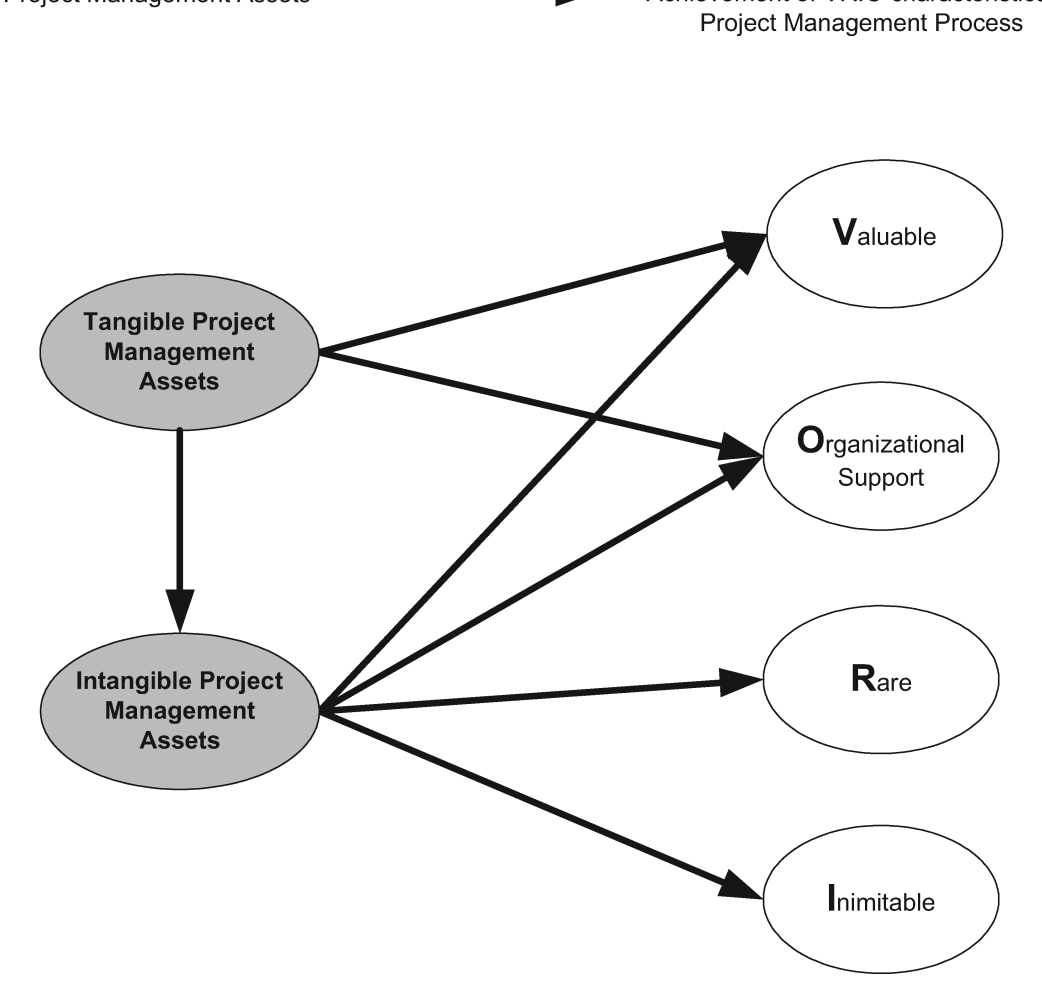
process being rare or inimitable. These hypotheses are stated as $H 7$ through $H 1 O$ below and portrayed as paths in Figure 2.

H7. Tangible project management assets will result in the project management process being Rare $(R)$ when mediated by intangible assets.

H8. Tangible project management assets will not directly result in the project management process being Rare $(R)$.

H9. Tangible project management assets will result in the project management process being Inimitable $(I)$ when mediated by intangible assets.

H1O. Tangible project management assets will not directly result in the project management process being Inimitable $(I)$.

\section{Methodology}

This paper uses data gathered from an online survey of a random sample of North American Project Management Institute ${ }^{\circledR}$ members to identify factors that comprise project management assets and competitive characteristics of the project management process. The survey design closely followed the format recommended by experts (Dillman et al., 1993; Fowler, 1992; Couper et al., 2001). We developed items for each latent variable, and created a survey instrument consisting of 80 questions, 12 demographic questions, and an open-ended question for additional input. We used a 7-point Likert scale with the anchors being "Strongly Agree" and "Strongly Disagree", with a "Not Applicable" category where relevant. We used multiple-item measures and minimized retrospective bias by focusing questions on the past year. A copy of the complete survey instrument is available upon request.

The response rate was 10.1 per cent (202 participants). About 60 per cent of the participants were from the USA and the rest from Canada. The male-to-female participant ratio was nearly 2:1. Two-thirds of the participants were between 30 and 49 years of age. Nearly three-quarters of the participants had their Project Management Professional designation. Over 90 per cent of the participants had an undergraduate degree. Most participants were in middle management positions or technical roles. About one-third of the participants had 6-9 years of experience and about another one-third had 10-19 years of experience. About two-third of the participants had been with their current company for less than nine years. Sixty-one per cent of the participants were in the top four industries: information industry (23.0 per cent); scientific and technical services industry (16.4 per cent); finance and insurance industry (12.0 per cent); manufacturing industry (9.8 per cent).

Exploratory factor analysis using SPSS ${ }^{\circledR}$ v. 13 was used to extract factors representing key elements of the project management process (independent variables) and factors representing the VRIO characteristics of the project management process (dependent variable). We used the Principal Components Extraction method with Varimax rotation and 0.40 as a cutoff to identify items with high loadings for inclusion with each factor (Conway and Huffcutt, 2003). Eigenvalues over one were used to extract reliable factors. Cronbach's alpha measures how well a set of items measures a single unidimensional latent construct. A reliability coefficient of 0.70 or higher is acceptable in the social sciences (Nunnally, 1978). We used this test to assess the internal consistency of the items within each construct. In addition we looked for factors consisting of three or more items. We extracted six factors for the independent variables and three factors for the dependent variable based on the requirement of 
MRN

30,7

466 three or more items. The rotated component matrices from the factor analysis are available in a prior publication (Jugdev and Mathur, 2006).

LISREL ${ }^{\circledR}$ v. 8.72 was used to assess the multivariate relationship between the factors representing project management process elements and the VRIO characteristics of the project management process. The sample size of 202 was adequate for a small-to-medium sized model (Tabachnick and Fidell, 2000). Path models based on the conceptual frameworks in Figures 1 and 2 were used for path analysis to test the hypothesized relationships between:

(1) Project management process assets (tangible and intangible) and the VRIO characteristics of the process without the mediating effect of intangible assets,

(2) project management process assets and the VRIO characteristics of the process with intangible assets mediating the relationship between the tangible assets and the VRIO characteristics of the process.

The results of the exploratory factor analysis, the correlations between factors, and the outcomes of the path analysis are presented and discussed in the section that follows.

\section{Discussion of results and findings}

Exploratory factor analysis

Exploratory factor analysis yielded three factors that represent tangible assets and one that represents intangible assets, the independent variables in our model. These factors together represent 52 per cent of the total variance of the original variables. These factors were labeled to reflect items that define them and are briefly described below. The number of items in the factor, Cronbach's alpha, and the percentage of variance explained by each are provided in parentheses. Three factors $(1,2$, and 3$)$ represent tangible assets; one represents intangible assets (4). These factors are expected to positively influence the dependent variable factors.

(1) Project management maturity (tangible) reflected the use of project management practices (e.g. a project management office, tools and techniques, methodology, standards, and processes), the use of program and portfolio management practices, and the addressing of the efficiency and effectiveness of practices (14 items; Cronbach's Alpha of 0.953; explains 14.1 per cent of variance).

(2) Training and development (tangible) involved managerial support for training and development and included development of project manager competences, support for $\mathrm{PMP}^{\circledR}$ certification, and a career path for project managers (8 items; Cronbach's Alpha of 0.931; explains 12.5 per cent of variance).

(3) Sharing know-what (tangible) included codified knowledge-sharing practices and reflected the use of databases, systems, intranets, best-practices databases, and processes for sharing knowledge (7 items; Cronbach's Alpha of 0.939; explains 11.9 per cent of variance).

(4) Sharing know-how (intangible) included the different ways in which tacit knowledge was shared (e.g. sharing knowledge informally, mentoring, stories, brainstorming, and shadowing) (11 items; Cronbach's Alpha of 0.867; explains 13.1 per cent of variance).

The emergence of the intangible asset factor (Sharing know-how) is a significant finding of this research, highlighting the importance of tacit knowledge in a discipline 
where there is a strong focus on tangible factors and a prevalence of codified project management practices. Drawing on the literature, and based on our findings, we view intangible assets and specifically the sharing of tacit knowledge in project management as a source of competitive advantage (Ray et al., 2004; Sussland, 2001; Teece, 1998).

Two additional factors were extracted as independent variables. These two factors represent undervalued sharing of know-how and knowledge and correspond to the lack of practices, incentives, and support for sharing know-how and knowledge across teams and departments within the companies represented by our survey participants. While these two factors explained an additional 7.3 per cent and 5.1 per cent of the variance respectively, they had a lower number of items and Cronbach's alpha compared to the four asset factors. We, therefore, do not include these two factors in our examination of the relationship between project management assets and competitive characteristics of the process.

The exploratory factor analysis yielded three factors for the dependent variable, identified as three of the four VRIO characteristics of the project management process in our conceptual model - Valuable, having Organizational Support, and Rare. The fourth expected characteristic from the VRIO framework, Inimitable, did not emerge as a factor. The item that describes project management as difficult to copy was, however, found included in the Rare factor, leading to the conclusion that there is an overlap between these two, Rare and Inimitable characteristics of project management assets. These three factors explain 55 per cent of the total variance of the original variables. These factors are briefly described below and number of items in the factor, Cronbach's alpha, and the percentage of variance explained by each are provided in parentheses.

(1) The Valuable factor involved survey items on project management providing economic value (e.g., improving business performance, increasing profitability, and responding to environmental threats and opportunities) (9 items; Cronbach's Alpha of 0.929; explains 25.1 per cent of variance).

(2) The Organizational support factor involved survey questions on management support, adequate resources for the discipline, and project management being an organization-wide undertaking (10 items; Cronbach's Alpha of 0.841; explains 21.3 per cent of variance).

(3) The Rare factor involved survey items that showed project management to be unique, controlled by a few firms, and difficult to copy (3 items; Cronbach's Alpha of 0.690; explains 8.7 per cent of variance).

\section{Correlations between factors}

The correlations coefficients between the seven key factors relevant to our models are provided in Table I. An analysis of the correlations between these factors showed a significant and moderate to strong correlation between the three tangible asset factors and the intangible factor. The correlations between the asset factors and the VRIO factors were all significant with varying levels of strength.

\section{Multivariate analysis}

Figures 1 and 2 were elaborated to the path models in Figures 3 and 4 . These path models link the four factors representing project management assets to the three factors representing the VRIO characteristics of the project management process. Figure 3 shows the path analysis results without the intangible factor (Sharing 
MRN

30,7

\section{8}

Table I.

Correlation coefficients

\section{$1 \quad 2$}

$2 \quad 3$

34

4

5

6

Project management maturity

Training and development

Sharing know-what

Sharing know-how

Valuable

Organizational support

Rare
$0.635 * *$

$0.489 * *$

$0.565^{* *}$

$0.658^{* *}$

$0.226^{* * * *}$
$0.539 * *$

$0.471 * *$

$0.686^{* * *}$

$0.243^{* *}$
$0.577^{* *}$

$0.489^{* * *}$

$0.380 * *$
Figure 3.

Path analysis results without the intangible factor (Sharing knowhow) in a mediating role

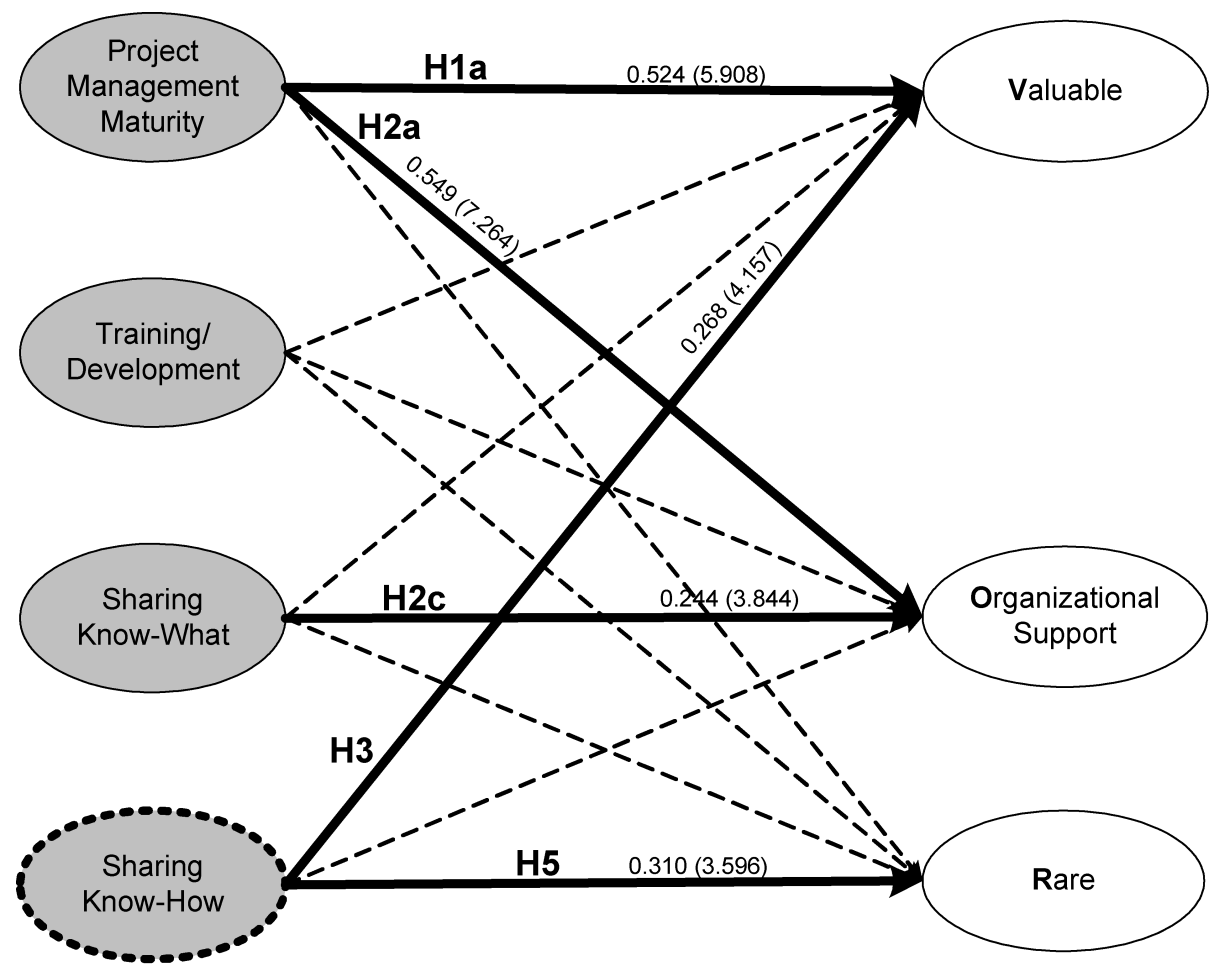

LEGEND

Path coefficients of significant paths are significant at alpha $=0.05$; $t$-statistics are in brackets
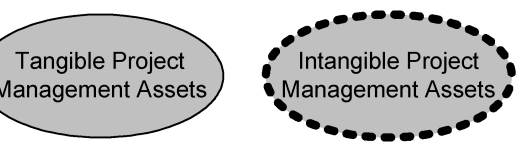

Not significant

Empirically supported 


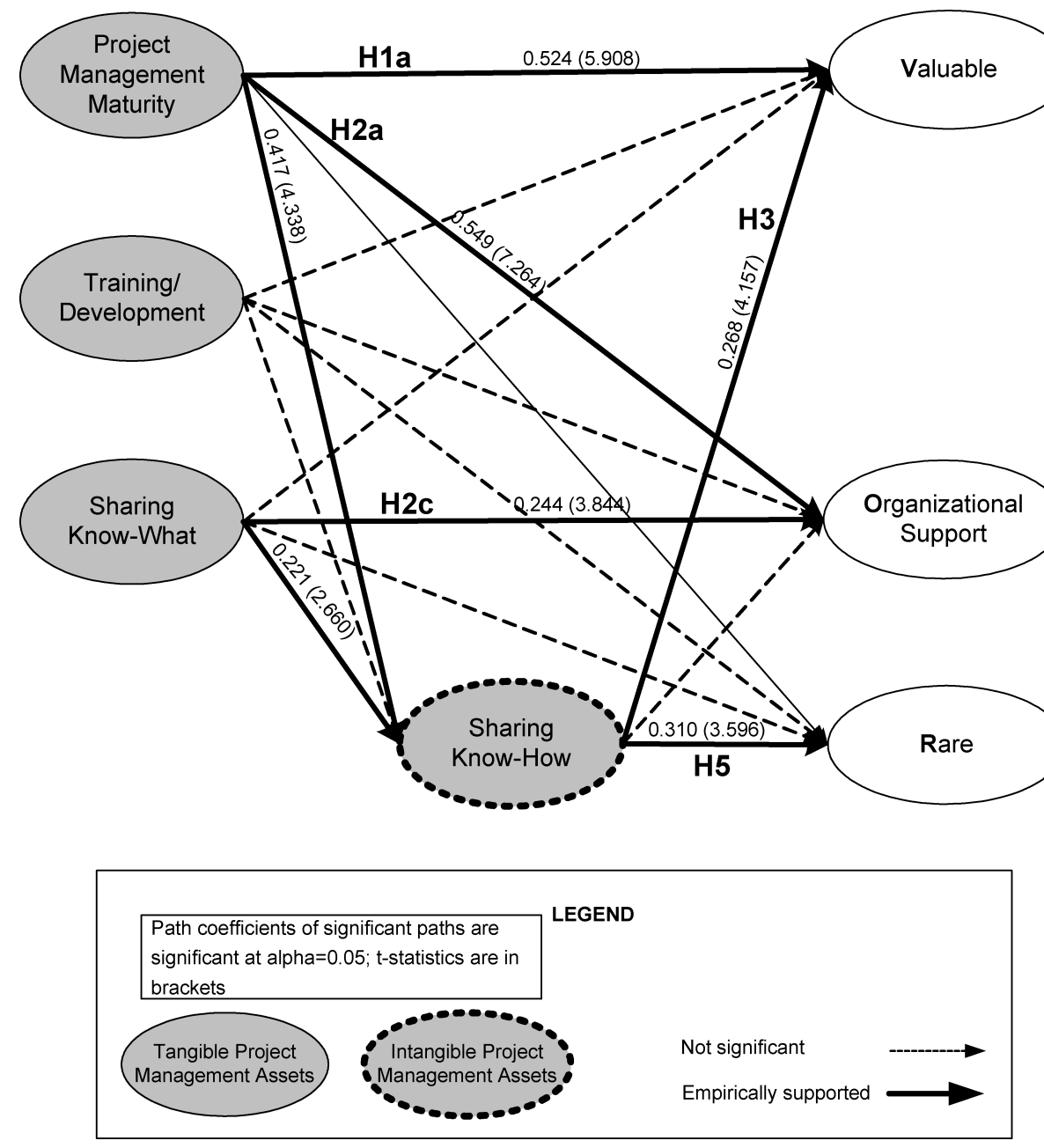

Figure 4.

Path analysis results with the intangible factor (Sharing know-how) in a mediating role

know-how) in a mediating role and Figure 4 shows the path analysis results with the intangible factor (Sharing know-how) in a mediating role between the tangible asset factors and the three factors representing the VRIO characteristics of the process. Path coefficients and $t$-values are provided for each significant path $(\mid t$-statistic $\mid>2)$ in Figures 3 and 4 .

We tested the hypotheses $H 1$ through $H 5, H 7$, and $H 8$ using path analysis for the path models in Figures 3 and 4. It was not possible for us to test hypotheses $H 6, H 9$, and $\mathrm{H} 10$ since Inimitable did not emerge as a factor in our Factor Analysis. The summary of the hypotheses and the outcomes are provided in Table II.

Hypotheses $H 7$ and $H 8$ were tested by comparing the path coefficients for the direct paths between the tangible asset factors and dependent factor Rare and the indirect paths between the tangible asset factors and Rare when mediated by Sharing knowhow. The comparative data are provided in Table III and illustrate the key finding of 


\section{MRN \\ 30,7}

470

Table II.

Hypotheses
Hypothesis

Supported

H1a. Project management maturity significantly predicts the project management process being Valuable

H1b. Training/development significantly predicts the project management process being Valuable

H1c. Sharing know-what significantly predicts the project management process being No Valuable

$H 2 a$. Project management maturity significantly predicts the project management process having Organizational support

$H 2 b$. Training/development significantly predicts the project management process having Organizational support

$H 2 c$. Sharing know-what significantly predicts the project management process Yes having Organizational support

H3. Sharing know-how significantly predicts the project management process being Yes Valuable

H4. Sharing know-how significantly predicts the project management process having No Organizational support

H5. Sharing know-how significantly predicts the project management process being Yes Rare

$H 7 a$. Project management maturity significantly predicts the project management $\quad$ Yes process being Rare when mediated by Sharing know-how

H7b. Training/development significantly predicts the project management process No being Rare when mediated by Sharing know-how

$H 7 c$. Sharing know-what significantly predicts the project management process being Yes Rare when mediated by Sharing know-how

H8a. Project management maturity does not directly, significantly predict the project Yes management process being Rare

H8b. Training/development does not directly, significantly predict the project Yes management process being Rare

$H 8 c$. Sharing know-what does not directly, significantly predict the project Yes management process being Rare

Notes: Hypotheses $\mathrm{H6}, \mathrm{H} 9$, and $\mathrm{H} 10$ were not tested since Inimitable did not emerge as a factor in our Factor Analysis

this research. The key finding is that intangible project management assets (in this study Sharing know-how) are a determinant of competitive advantage from the project management process, both directly and in a mediating role between tangible assets and process outcomes.

\begin{tabular}{lcc}
\hline & $\begin{array}{c}\text { Path coefficient for } \\
\text { direct path between } \\
\text { tangible asset factor } \\
\text { and Rare }\end{array}$ & $\begin{array}{c}\text { Path coefficient for indirect } \\
\text { path between tangible } \\
\text { asset factor and Rare mediated } \\
\text { by Sharing know-how }\end{array}$ \\
\hline Project management maturity & $0.152(1.280)$ & $\mathbf{0 . 1 2 9 ( 2 . 7 6 8 )}$ \\
Training/development & $-0.032(-0.309)$ & $0.012(0.422)$ \\
Sharing know-what & $-0.011(-0.108)$ & $\mathbf{0 . 0 6 9 ( 2 . 1 3 9 )}$
\end{tabular}

Notes: $t$-values are shown in parentheses and significant paths are bolded. Paths coefficients are significant at alpha $=0.05$ 
(1) We find that Sharing know-how significantly predicts the project management process being Rare (H5).

(2) We find that two of the tangible asset factors (Project management maturity and Sharing know-what) significantly predict the project management process being Rare when mediated by Sharing know-how (H7a and $H 7 c$ ). However, none of the tangible asset factors (Project management maturity, training and development, nor sharing know-what) directly predict the project management process being Rare.

\section{Conclusion}

This paper draws on the Resource Based View of the firm and uses data gathered from an online survey of a random sample of North American Project Management Institute ${ }^{\circledR}$ members to examine the relationship between factors that represent project management assets (tangible and intangible) and factors that represent competitive characteristics of the project management process (VRIO). We examine the direct relationship between the project management factors and the VRIO characteristics of the process and also examine the mediating role of intangible factors in the relationship between the tangible factors and the VRIO characteristics. We find that intangible project management assets contribute to a company's competitive position by resulting in the project management process being both Valuable and Rare. We find that tangible assets, while valuable, do not directly result in the project management process being rare and are therefore not in themselves a source of competitive advantage. We find, however, that when mediated by intangible project management assets, tangible project management assets do result in the process being both Valuable and Rare, contributing to a company's competitive position.

Our findings suggest that companies attempting to leverage their project management process as a source of competitive advantage need to invest in intangible project management assets, in addition to investment in tangible project management assets. Intangible project management assets are based on tacit knowledge which is not readily transferable or copied like tangible project management assets. While companies are increasingly investing in tangible project management assets such as project management tools and techniques, methodologies, and project management offices, our data shows that sharing of project management know-how and knowledge across teams and departments is undervalued in the companies represented in our sample. This highlights a need for senior managers and project management practitioners to recognize and promote the importance of processes and practices for facilitating the development and sharing of tacit project management knowledge intangible assets which provide competitive advantage. Processes and practices that facilitate the sharing of tacit knowledge such as mentoring, brainstorming, learning through stories, and shadowing are used informally and sometimes formally in project management contexts. However, these processes and practices have not been the focus of management attention and warrant increased investment.

This paper's contribution is positioned at the intersection of the literature on the Resource Based View of the firm and the literature on project management, in the belief that the project management process can be a source of competitive advantage. Our conceptual model draws on the VRIO framework and suggests that intangible project management assets result in the project management process being Valuable, Rare, and Inimitable while tangible project management assets do not result in the process being Rare or Inimitable. In this model, we conceptualize a mediating role for intangible 
MRN

30,7

472

project management assets in the relationship between tangible project management assets and the competitive characteristics of the project management process. Our empirical results support our conceptual model.

The limitations of this study are acknowledged and are being addressed in our ongoing research. While the sample size for this study was fair and the Project Management Institute has a membership of over 222,734 (as of November 2006, worldwide), the use of one membership mailing list represents an element of sample bias in terms of study generalizability. The limited scale of the study calls for replication and elaboration of findings through large-scale empirical research. We plan to conduct the next survey with more than one membership mailing list. The study was also limited by the specifics of the instrument. Additional literature research and analysis of our current database are underway to refine the instrument. There is a clear need to distinguish between the constructs of Rare and Inimitable through the use of more careful definition of items and the use of more items. There is also a need to more specifically address values in the survey in addition to factors that encompass processes and practices. In addition, we acknowledge the need for increased attention to organizational culture, group dynamics, and social capital in future research, since these are important to the sharing of tacit knowledge.

We find that the contribution of project management assets to a company's competitive position is understudied as is the importance of intangible project management factors within the set of project management assets. This paper contributes to management theory and practice through an empirical study targeted at improved understanding of the role of intangible project management assets as determinants of competitive advantage.

\section{References}

Amit, R. and Schoemaker, P.J.H. (1993), "Strategic assets and organizational rent", Strategic Management Journal, Vol. 14, pp. 33-46.

AoM (2005), "A new vision of management in the 21st century", Academy of Management, Honolulu, HI.

Barney, J.B. (1991), "Firm resources and sustained competitive advantage", Journal of Management, Vol. 17, pp. 99-120.

Barney, J.B. (1998), "On becoming a strategic partner: the role of human resources in gaining competitive advantage”, Human Resource Management, Vol. 37, pp. 31-46.

Barney, J.B. (1999), "How a firm's capabilities affect boundary decisions", Sloan Management Review, Vol. 40, pp. 137-45.

Barney, J.B. (2002), Gaining and Sustaining Competitive Advantage, Prentice-Hall, Inc., Upper Saddle River, NJ.

Barney, J.B. and Zajac, E.J. (1994), "Competitive organizational behavior: toward an organizationally-based theory of competitive advantage”, Strategic Management Journal, Vol. 15, pp. 5-9.

Castanias, R.P. and Helfat, C.E. (1991), "Managerial resources rents", Journal of Management, Vol. 17, pp. 155-71.

Castanias, R.P. and Helfat, C.E. (2001), "The managerial rents model: theory and empirical analysis", Journal of Management, Vol. 27, pp. 661-78.

Chakraborty, K. (1997), "Sustained competitive advantage: a resource-based framework", Advances in Competitiveness Research, Vol. 5, pp. 32-63. 
Conway, J.M. and Huffcutt, A.I. (2003), "A review and evaluation of exploratory factor analysis practices in organizational research", Organizational Research Methods, Vol. 6, pp. 147-68.

Couper, M.P., Traugott, M.W. and Lamias, M.J. (2001), "Web survey design and administration”, Public Opinion Quarterly, Vol. 65, pp. 230-53.

DeFillippi, R.J. and Arthur, M.B. (1998), "Paradox in project-based enterprise: the case of film making”, California Management Review, Vol. 40, pp. 125-39.

Dillman, D.A., Sinclair, M.D. and Clark, J.R. (1993), "Effects of questionnaire length, respondentfriendly design, and a difficult question on response rates for occupant-addressed census mail surveys", Public Opinion Quarterly, Vol. 57, pp. 289-304.

Eisenhardt, K. and Santos, F. (2000), "Knowledge-based view: a new theory of strategy?", in Pettigrew, A., Thomas, H. and Whittington, R. (Eds) Handbook of Strategy and Management, 1st ed., Sage, London.

ESI-International (2001), ESI International.

Fernie, S., Green, S.D., Weller, S.J. and Newcombe, R. (2003), "Knowledge sharing: Context, confusion, and controversy", International Journal of Project Management, Vol. 21, pp. $177-87$.

Foss, N.J. (Ed.), (1997), Resources, Firms, and Strategies: A Reader in the Resource-based Perspective, Oxford University Press, Oxford.

Fowler, F.J. (1992), "How unclear terms affect survey data", Public Opinion Quarterly, Vol. 56, pp. 218-31.

Granovetter, M. (1985), "Economic action and social structure: the problem of embeddedness", American Journal of Sociology, Vol. 91, pp. 481-510.

Hartman, F.T. (2000), Don't Park your Brain Outside: A Practical Guide to Improving Shareholder Value with SMART Project Management, Project Management Institute, Upper Darby, PA.

Hawawini, G., Subramanian, V. and Verdin, P.J. (2002), "Is performance driven by industry - or firm-specific factors? A new look at the evidence”, Strategic Management Journal, Vol. 24, pp. 1-16.

Ibbs, C.W. and Kwak, Y.H. (2000), "Assessing project management maturity", Project Management Journal, Vol. 31, pp. 32-43.

Jugdev, K. and Mathur, G. (2006), "Project management elements as strategic assets: preliminary findings", Management Research News, Vol. 29, pp. 604-17.

Jugdev, K. and Thomas, J. (2002), "Project management maturity models: the silver bullets of competitive advantage", Project Management Journal, Vol. 33, pp. 4-14.

Kaplan, S., Schenkel, A., Von Krogh, G. and Weber, C. (2001), "Knowledge-based theories of the firm in strategic management: a review and extension”, Sloan Working Paper 4216-01, MIT.

Kloppenborg, T. and Opfer, W. (2002), "The current state of project management research: trends, interpretations, and predictions", Project Management Journal, Vol. 33, pp. 5-18.

Kogut, B. (2000), "The network as knowledge: generative rules and the emergence of structure", Strategic Management Journal, Vol. 21, pp. 405-25.

Kogut, B. and Zander, U. (1993), "Knowledge of the firm and the evolutionary theory of the multinational corporation", Journal of International Business Studies, Vol. 24, pp. 625-44.

Koskela, L. and Howell, G. (2002), "The underlying theory of project management is obsolete", in Slevin, D.P., Pinto, J.K. and Cleland, D.I. (Eds), Frontiers of Project Management Research and Application, Project Management Institute, Seattle, WA.

Lesser, E.L. (Ed.), (2000), Knowledge and Social Capital: Foundations and Applications, Butterworth and Heinemann, Boston, MA. 
MRN

30,7

474
Lopez, V.A. (2001), "An overview review of the resource-based view (RBV) of the firm, drawing on recent Spanish management research”, Irish Journal of Management, Vol. 22, pp. 105-20.

Mata, F.J., Fuerst, W.L. and Barney, J.B. (1995), "Information technology and sustained competitive advantage: a resource-based analysis”, MIS Quarterly, Vol. 19, pp. 487-507.

MicroFrame (2001), "Project management maturity model", Business Engine: Micro Frame Technologies and Project Management Technologies Inc.

Montealegre, R. (2002), "A process model of capability development: lessons from the electronic commerce strategy at Bolsa de Valores de Guayaquil”, Organization Science, Vol. 13, pp. 514-31.

Nonaka, I. (1994), “A dynamic theory of organizational knowledge creation”, Organization Science, Vol. 5, pp. 14-37.

Nonaka, I., Toyama, R. and Konno, N. (2000), "SECI, $B a$ and Leadership: a unified model of dynamic knowledge creation”, Long Range Planning, Vol. 33, pp. 5-34.

Nunnally, J.C. (1978), Psychometric Theory, McGraw-Hill, New York, NY.

Packendorff, J. (1995), "Inquiring into the temporary organization: new directions for project management", Scandinavian Journal of Management, Vol. 11, pp. 319-33.

PMI (2004), A Guide to the Project Management Body of Knowledge (PMBOK ${ }^{\circledR}$ Guide), Project Management Institute, Newtown Square, PA.

Polanyi, M. (1966), The Tacit Dimension, Doubleday and Company, Garden City, New York, NY.

Ray, G., Barney, J.B. and Muhanna, W.A. (2004), "Capabilities, business processes, and competitive advantage: choosing the dependent variable in empirical tests of the resourcebased view”, Strategic Management Journal, Vol. 25, pp. 23-37.

Rumelt, R.P., Schendel, D.E. and Teece, D.J. (1994), "Fundamental issues in strategy”, in Rumelt, R.P., Schendel, D.E. and Teece, D.J. (Eds), Fundamental Issues in Strategy, Harvard Business School Press, Cambridge, MA.

Sabherwal, R. and Becerra-Fernandez, I. (2003), "An empirical study of the effects of knowledge management processes at individual, group, and organizational levels", Decision Sciences, Vol. 34, pp. 225-60.

Sussland, W.A. (2001), "Creating business value through intangibles", Journal of Business Strategy, Vol. 22, pp. 23-8.

Tabachnick, B.G. and Fidell, L.S. (2000), Using Multivariate Statistics, HarperCollins College Publishers, Northridge, CA.

Teece, D.J. (1998), "Capturing value from knowledge assets: the new economy, markets for knowhow, and intangible assets", California Management Review, Vol. 40, pp. 55-79.

Teece, D.J., Pisano, G. and Shuen, A. (1997), "Dynamic capabilities and strategic management", Strategic Management Journal, Vol. 18, pp. 509-33.

Tsoukas, H. (1991), "The missing link: a transformational view of metaphors in organizational science", Academy of Management Review, Vol. 16, pp. 566-85.

Ulri, B. and Ulri, D. (2000), "Project management in North America: stability of the concepts", Project Management Journal, Vol. 31, pp. 33-43.

Wiggins, R.R. and Ruefli, T.W. (2002), "Sustained competitive advantage: temporal dynamics and the incidence and persistence of superior economic performance”, Organization Science, Vol. 13, pp. 82-104.

Zahra, S.A. and Nielsen, A.P. (2002), "Sources of capabilities, integration, and technology commercialization”, Strategic Management Journal, Vol. 23, pp. 377-98. 


\begin{abstract}
About the authors
Gita Mathur is an Associate Professor in the Department of Organization and Management in the College of Business at San José State University. Her research interests are in the management of technological innovation and product and service development processes. She has held engineering and management positions in the semiconductor industry and has served as a management consultant to several technology-based companies. She holds a $\mathrm{PhD}$ in electrical engineering from Rensselaer Polytechnic Institute, Troy, New York and a DBA in technology and operations management from Harvard Business School, Boston, MA. Gita Mathur is the corresponding author and can be contacted at: mathur_g@cob.sjsu.edu

Kam Jugdev is an Associate Professor of Project Management and Strategy in the MBA program at Athabasca University in Alberta and an Adjunct Professor at the Schulich School of Engineering, University of Calgary, Alberta. Her specific areas of interest and research include project management as a source of competitive advantage, project lessons learned, project management maturity models, project success/failure, and project management education. Jugdev actively contributes to the advancement of academic and professional communities of management practice.

Tak Shing Fung is a Senior Statistical Consultant in Information Technologies, Sessional Instructor in Mathematics \& Statistics, and an Adjunct Assistant Professor in Faculty of Nursing, University of Calgary. His specific areas of interest and research are Brownian motion and statistical analysis. Dr. Fung has over 23 years of statistical consulting experience in different disciplines including medicine, nursing, kinesiology, education, social sciences, environmental design, social work, biology, chemistry, management, and engineering.
\end{abstract}

To purchase reprints of this article please e-mail: reprints@emeraldinsight.com Or visit our web site for further details: www.emeraldinsight.com/reprints 